\title{
The Importance of Cytosolic Glutamine Synthetase in Nitrogen Assimilation and Recycling
}

\author{
Stéphanie M. Bernard ${ }^{1}$ and Dimah Z. Habash $^{2}$
}

${ }^{1}$ Earth Sciences Division, Lawrence Berkeley National Laboratory, One Cyclotron Road, Berkeley, CA
94720, USA;
${ }^{2}$ Plant Science Department, Centre for Crop Genetic Improvement, Rothamsted Research, Harpenden,
Hertfordshire, AL5 2JQ, UK

Author for correspondence:

Stéphanie M. Bernard

Tel: +1 5104866125

Email: SMBernard@lbl.gov

\section{Summary}

Glutamine synthetase assimilates ammonium into amino acids, thus it is a key enzyme for nitrogen metabolism. The cytosolic isoenzymes of glutamine synthetase assimilate ammonium derived from primary nitrogen uptake and from various internal nitrogen recycling pathways. In this way, cytosolic glutamine synthetase is crucial for the remobilization of protein-derived nitrogen. Cytosolic glutamine synthetase is encoded by a small family of genes that are well conserved across plant species. Members of the cytosolic glutamine synthetase gene family are regulated in response to plant nitrogen status, as well as to environmental cues, such as nitrogen availability and biotic/abiotic stresses. The complex regulation of cytosolic glutamine synthetase at the transcriptional to post-translational levels is key to the establishment of a specific physiological role for each isoenzyme. The diverse physiological roles of cytosolic glutamine synthetase isoenzymes are important in relation to current agricultural and ecological issues.

Abbreviations: ATP, adenosine triphosphate; GDH, glutamate dehydrogenase; GOGAT, glutamate
synthase; GS, glutamine synthetase; PAL, phenylalanine ammonia lyase; QTL, quantitative trait locus.

Key words: abiotic stress, biotic stress, glutamine synthetase (GS), nitrogen metabolism, quantitative trait locus (QTL), regulation, remobilization, seed.

\section{Introduction}

Nitrogen, a key element for plant growth and reproduction, is an essential building block of nucleic acids and proteins. Plants can store nitrogen in large amounts within enzymes involved in carbon fixation, such as leaf Rubisco (Stitt \& Schulze, 1994). However, nitrogen is also often a limiting nutrient in many natural environments, and different plant species have evolved specific strategies to acquire nitrogen from their environments and assimilate it into organic compounds. Glutamine synthetase (GS, E.C. 6.3.1.2) plays a major role in fixing ammonium $\left(\mathrm{NH}^{+4}\right)$ to form the amino acid glutamine. The cytosolic isoform of GS is particularly important for assimilating ammonium from different sources, for both primary nitrogen assimilation and recycling. Recent studies have led to a better understanding of the specific roles of this isoform of GS in flowering plants and conifers. Here, we focus on the current knowledge of cytosolic GS and its central role in nitrogen assimilation and recycling.

Nitrogen is the most abundant element in the atmosphere. In some systems, biological nitrogen fixation of atmospheric $\mathrm{N}_{2}$ contributes to much of the primary nitrogen source available to plants, mostly through symbiosis with diazotrophic bacteria (Oldroyd \& Downie, 2008). Symbiosis 


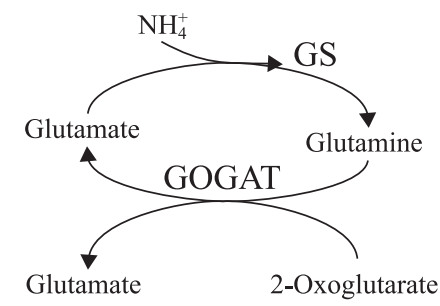

Fig. 1 The glutamine synthetase-glutamate synthase (GS-GOGAT) cycle.

with arbuscular mycorrhizal fungi and ectomycorrhiza has also been shown to improve the capacity of plants to take up nutrients, including nitrogen (Buscot et al., 2000; He et al., 2003). The nitrogen sources directly available to plants include inorganic nitrogen compounds, such as nitrate and ammonium, as well as organic compounds, such as amino acids (e.g. glycine, alanine, glutamic acid, aspartic acid) and small peptides (Schimel \& Bennett, 2004; Bardgett, 2005). In nonfertilized ecosystems, the majority of mineral nitrogen is produced by microbial mineralization of organic nitrogen (Paul \& Clark, 1996). The nature of nitrogen sources varies between soil types rich in ammonium, such as boreal forest soil, and others rich in nitrate, such as agricultural fields (Britto \& Kronzucker, 2005). In addition, the soil concentration of inorganic nitrogen can range from micromolar to molar (Britto \& Kronzucker, 2005). Mechanisms for optimizing nitrogen capture in a variety of environments have evolved in plants. The uptake of soil nitrate and ammonium by plant roots has been well characterized at the physiological and molecular level, and several multigene families of low- and high-affinity nitrate and ammonium transporters have been described and studied in detail (Glass et al., 2002; Miller et al., 2007).

The main pathways of inorganic nitrogen assimilation and remobilization in plants have been established at the biochemical level. GS is a key enzyme, because it catalyses the adenosine triphosphate (ATP)-dependent fixation of ammonium to the $\delta$-carboxyl group of glutamate to form glutamine (Fig. 1). The enzyme glutamate synthase (GOGAT, E.C. 1.4.7.1) catalyses the conversion of glutamine and 2-oxoglutarate to two molecules of glutamate, thus providing glutamate for ammonium assimilation. The net outcome of the GS-GOGAT cycle is the production of glutamate, which can then be incorporated into other amino acids through the action of aminotransferases or transaminases (Forde \& Lea, 2007). Specific amino acids can subsequently become precursors for all nitrogen-containing organic molecules, such as proteins, chlorophyll, cytochrome/phytochrome, secondary metabolites and nucleic acids. The product of GS, glutamine, is itself the main form of organic nitrogen for transport in the phloem of rice (Hayashi \& Chino, 1990; Yamaya \& Oaks, 2004) and in the xylem of poplar (Sauter $\&$ van Cleve, 1992). Arginine and asparagine are also commonly involved in nitrogen transport, asparagine in particular being an efficient compound for nitrogen transport and storage as a result of its high molecular nitrogen to carbon ratio (for a review, see Lea et al., 2007).

In plant cells, nitrogen assimilation is compartmentalized between the cytosol and chloroplast, in relation to the different sources of ammonium. Primary sources of ammonium include direct ammonium uptake from the soil and the reduction of nitrate and atmospheric $\mathrm{N}_{2}$, whereas secondary sources consist of amino acid catabolism following protein degradation, photorespiratory nitrogen cycling and the production of ammonium by phenylalanine ammonia lyase (PAL; E.C. 4.3.1.5) and asparaginase (E.C. 3.5.1.1). Nitrate is first reduced into nitrite via nitrate reductase (E.C. 1.6.1.1), which is cytosolic, after which the chloroplast-located nitrite reductase (E.C. 1.7.7.1) catalyses the reduction of nitrite into ammonium. Photorespiratory nitrogen cycling produces large amounts of ammonium in the mitochondria (Keys et al., 1978). During leaf senescence, although some amino acids generated through protein breakdown may be converted to alternative amino acids and/or exported via the phloem to developing organs (Hortensteiner \& Feller, 2002), other amino acids are degraded further, leading to the production of free ammonium. For example, in tobacco and ryegrass leaves, protein degradation during senescence coincides with increased levels of ammonium (Schjoerring et al., 1993; Masclaux et al., 2000; Mattsson \& Schjoerring, 2003).

Glutamate dehydrogenase (GDH; E.C. 1.4.1.2) and asparaginase have been described as sources of ammonium deriving from the catabolism of amino acids. GDH specifically catalyses the reversible amination/deamination between 2oxoglutarate and glutamate; its physiological role in nitrogen metabolism has been the subject of controversy (Lea \& Miflin, 2003; Forde \& Lea, 2007). Although some evidence suggests a role for GDH in ammonium assimilation, most studies indicate that GDH functions primarily in the deamination direction, thereby producing ammonium in the mitochondria (Lea \& Miflin, 2003). It is most likely that GDH functions as a shunt to divert some of the carbon skeleton from nitrogen metabolism to carbon metabolism and the tricarboxylic acid cycle (Miflin \& Habash, 2002; Lea \& Miflin, 2003). Asparaginase catalyses the hydrolysis of asparagine to form ammonium and aspartate, thereby constituting the major route for asparagine catabolism.

Focusing primarily on cytosolic GS, we discuss below the current knowledge of the enzyme structure, gene family and evolution. We then examine information regarding cytosolic GS regulation in the context of specific roles with regard to primary nitrogen assimilation and recycling.

\section{Different GS isoforms have evolved}

Three types of GS have been described in living organisms, based on molecular mass, quaternary structure and gene sequences. GSI and GSII are both present in eukaryotes and prokaryotes, with GSI being more abundant in prokaryotes 
and GSII in eukaryotes. In addition, a third type (GSIII) has been described in Bacteroides, Butyvibrio and some cyanobacteria (Hill et al., 1989; García-Dominguez et al., 1997). Kumada et al. (1993) estimated that GSI and GSII arose from gene duplication c. $3500 \mathrm{Mya}$, based on the phylogenetic tree calibrated by Dickerson's estimate that animal and plant kingdoms diverged 1200 Mya. This study suggests that GS genes are one of the oldest existing and functioning genes. In higher plants, the GSII type is the most abundant, although some recent studies have shown the presence of GSI-encoding genes in Medicago truncatula, Arabidopsis thaliana and sugarcane (Saccharum spp.) (Mathis et al., 2000; Nogueira et al., 2005). Thus far, the function of these GSI-type genes remains unknown in plants; GSII genes have been better characterized. The atomic structure of maize cytosolic GS has recently been elucidated at 2.63-, 3.50- and 3.80- $\AA$ resolutions, indicating that plant GS polypeptides (Type II) form decamers (Unno et al., 2006), which differ from the dodecameric structure of bacterial GS (Type I) (Almassy et al., 1986; Krajewski et al., 2005). Cytosolic GS decamers, composed of two face-to-face pentameric rings of subunits, contain 10 active sites, with each site being formed between every two adjacent subunits in a pentamer (Unno et al., 2006).

In higher plants, two isoforms of GS (Type II) were first resolved by ion exchange chromatography. The cytosolic (GS1) isoform was the first to be eluted, followed by the plastidic (GS2) form (McNally \& Hirel, 1983), although the opposite elution pattern has been described in some species (Woodall et al., 1996; Orea et al., 2002). They also differ by molecular mass, with the plastidic isoform being larger $(c .44-45 \mathrm{kDa})$ than the cytosolic isoform (c.38-40 kDa) (Forde \& Cullimore, 1989). The relative abundance of GS isoforms varies within different organs of the same plant and within different plant species, depending on either their photosynthetic type or environmental growth conditions (McNally \& Hirel, 1983). In the mature green leaves of $\mathrm{C}_{4}$ plants, the relative amount of cytosolic to chloroplastic GS is much higher than in $\mathrm{C}_{3}$ plants, and this relates to $\mathrm{C}_{4}$ metabolism (Becker et al., 1993). Cytosolic and chloroplastic isoenzymes are regulated differently within specific cell types and organs, and in response to different developmental, metabolic and environmental cues. This specialization ensures a rapid reassimilation of ammonium derived from multiple sources (Miflin \& Habash, 2002). Overall, these two major GS isoforms play primarily nonoverlapping roles in plant nitrogen assimilation, with chloroplastic GS holding a major role in ammonium assimilation within photorespiratory nitrogen cycling (Wallsgrove et al., 1987; Leegood et al., 1995). The roles and regulation of chloroplastic GS have been discussed elsewhere (Cren \& Hirel, 1999; Zozaya-Hinchliffe et al., 2005; Betti et al., 2006).

In angiosperms, the chloroplastic isoenzyme is encoded by one gene, whereas two to five genes may encode the cytosolic form. In conifers, the functional expression of GS2 has so far not been demonstrated, suggesting that cytosolic GS is involved in nitrogen assimilation related to photosynthetic metabolism (Cánovas et al., 2007). Studies of GS gene families were first carried out in legume species, particularly Phaseolus vulgaris (Lara et al., 1983), Pisum sativum (Tingey et al., 1987) and Medicago truncatula (Stanford et al., 1993). More recently, GS gene families have been described in nonlegume plant species, such as Zea mays (Li et al., 1993), Arabidopsis thaliana (Ishiyama et al., 2004c), rice (Oryza sativa; Ishiyama et al., 2004a), wheat (Triticum aestivum; Bernard et al., 2008), potato (Solanum tuberosum; Teixeira et al., 2005) and sugarcane (Saccharum spp.; Nogueira et al., 2005). GS gene and protein sequences are well conserved both within and across species. For example, in wheat, members of the cytosolic GS gene family are $c .80 \%$ identical at the protein level (Bernard et al., 2008). Some key domains of the GS protein have been characterized, such as ATP-binding and glutamate-binding sites. Site-directed mutagenesis studies have demonstrated the functionality of some highly conserved residues in cytosolic GS polypeptide. For example, the aspartic acid at position 56 on the glutamine $\alpha$-polypeptide from $P$. vulgaris is essential for transferase activity, whereas the glutamic acid residue (position 297) is possibly involved in stabilizing the transition state for a reaction subsequent to ammonium binding (Clemente \& Marquez, 1999a,b). Clemente \& Marquez (2000) also demonstrated that the cysteine residue at position 92 is important for thermal stability. Further, recent point-mutation studies in rice and maize have identified particular residues that are critical in determining the kinetic characteristics of cytosolic GS isoenzymes and heat tolerance (Ishiyama et al., 2004a,b; Unno et al., 2006). The occurrence of isoenzymes with distinct biochemical characteristics, together with the heteromeric nature of the GS enzyme, could lead to many GS isoenzymes if these were expressed in the same cells and at the same time. However, the functional significance of these isoenzymes has not been studied in vivo.

Phylogenetic studies of GS nucleotide or amino acid sequences have shown that chloroplastic and cytosolic GSs form two sister groups (Doyle, 1991; Pesole et al., 1991) and have evolved through gene duplication (Biesiadka \& Legocki, 1997). Kumada et al. (1993) proposed that the common ancestor of the two genes diverged an estimated $300 \mathrm{Mya}$, based on a phylogenetic tree calibrated by Dickerson's estimate that animal and plant kingdoms diverged 1200 Mya. This analysis suggests that the duplication occurred earlier than the monocot/dicot divergence. Chloroplastic GS is also present in Ginkgo biloba (Garcia-Gutierrez et al., 1998), but absent in pine species. In Pinus sylvestris, two cytosolic GS genes have been identified, suggesting that the duplication of an ancestral cytosolic GS occurred long before the divergence of gymnosperms/angiosperms (Sáez et al., 2000). Doyle (1991) proposed that members of the cytosolic GS gene family in plants have evolved by duplication of an ancestral cytosolic GS gene and the evolution of separate gene copies to fulfil 
Fig. 2 The central role of cytosolic glutamine synthetase (GS) in plant growth and seed production. The central circle highlights the function of GS fixing inorganic nitrogen $(\mathrm{N})$ into amino acids that can be transported to developing tissues and organs. Sources of ammonium are highlighted around the central circles. GOGAT, glutamate synthase.

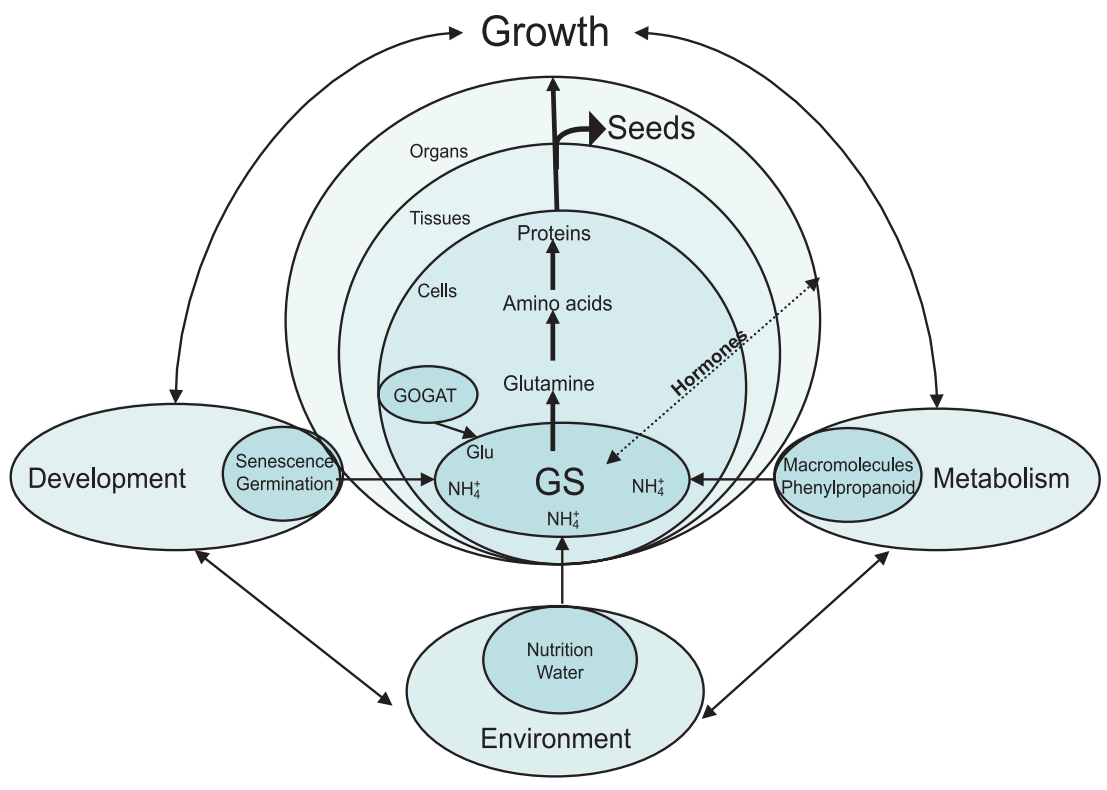

has shown that cytosolic GS sequences from plant species that can establish symbiotic relationships with either Rhizobia or Frankia cluster in three groups (Biesiadka \& Legocki, 1997; Kim et al., 2004). These groups do not seem to correspond to functionally different subfamilies, as each contains one cytosolic GS isoform involved in assimilating ammonium from $\mathrm{N}_{2}$ fixation. Cytosolic GS proteins from the Poaceae family also form three separate clades; however, these correspond to three functionally distinct subfamilies of cytosolic GS (Bernard, 2005; Hirel et al., 2007a; Bernard et al., 2008). Given the roles of some of the cytosolic GS isoforms in nitrogen assimilation and recycling, we believe that the evolution of these genes merits further attention.

In the three major cereal crops, studies have uncovered quantitative trait loci (QTLs) for cytosolic GS proteins and/or GS activity, demonstrating the existence of variation for GS in maize (Hirel et al., 2001), rice (Obara et al., 2001, 2004) and wheat cultivars (Habash et al., 2007). In these studies, some of the QTLs were localized to the mapped structural GS genes, establishing allelic variation, whereas others did not co-localize with the mapped GS genes, demonstrating that other genetic elements are influencing the activity or protein abundance of GS isoenzymes. These studies support and beautifully illustrate the complexity of the regulation of GS isoenzymes, discussed below.

\section{Cytosolic GS isoenzymes are regulated at transcriptional to post-translational levels and hold specific roles}

Plant GSs may be regulated at several levels: (1) transcription of different gene family members; (2) processing and stabilization of the transcripts; (3) translation; (4) subcellular localization, processing or modification of the GS polypeptide; (5) assembly of an active enzyme; (6) post-translational modification of the enzyme; and/or (7) enzyme degradation (Forde \& Cullimore, 1989; Temple et al., 1993; Cren \& Hirel, 1999). Transcriptional controls are considered to be particularly important in determining GS polypeptide abundance and cellular localization patterns (Cren \& Hirel, 1999). The complex regulation of cytosolic GS is key to the establishment of a specific physiological role for each isoenzyme (Fig. 2). The physiological roles for cytosolic GS are also closely related to the sources of ammonium discussed previously.

\section{Cytosolic GS assimilates ammonium from primary sources in roots, nodules and leaves}

\section{Ammonium uptake from soil}

The localization of cytosolic GS transcripts and polypeptides in roots has led to suggestions that it is involved in the assimilation of ammonium from primary nitrogen uptake (Sukanya et al., 1994; Ishiyama et al., 2004a,c). Furthermore, in situ hybridization and promoter-green fluorescent protein fusion studies on the localization of rice and $A$. thaliana GS gene expression have shown that the location of $O s G \ln 1 ; 2$ transcripts is consistent with the site of ammonium uptake, as indicated by the localization of ammonium transporters (Sonoda et al., 2003; Ishiyama et al., 2004a; Tabuchi et al., 2007). Studies in rice have suggested that OsNADH-GOGAT1 provides glutamate for ammonium assimilation by cytosolic GS in the cell layers at the root surface (Ishiyama et al., 2003; Tabuchi et al., 2007). Ferredoxin-GOGAT may be involved when excess ammonium is present and reaches the central cylinder and root cortex (Tabuchi et al., 2007). 
The role of root cytosolic GS in total plant primary nitrogen assimilation is not well understood, especially for species primarily assimilating nitrogen in the shoot. Furthermore, a high level of GS activity in the root was negatively correlated with above-ground biomass in Lotus japonicus (Limami et al., 1999). Pea plants overexpressing a soybean GS1 under the control of a root-specific promoter showed no consistent effect on total biomass (Fei et al., 2003). Of the two lines showing high root GS activity, one had decreased biomass and the other showed no significant difference. Lian et al. (2005) found a QTL for root weight that was localized in the vicinity of the structural root cytosolic GS gene when rice plants were grown under low nitrogen. Further studies are necessary to firmly establish the contribution of root cytosolic GS in total nitrogen assimilation, especially considering the different nitrogen sources and levels of nitrogen availability. Cruz et al. (2006) showed that a high level of GS activity in the dark, in either roots or leaves, was necessary for plants to tolerate high levels of ammonium in their growth medium.

Furthermore, Finnemann \& Schjoerring (1999) demonstrated that ammonium could be translocated from the root to the leaf through the xylem, contributing up to $11 \%$ of the total amount of nitrogen translocated in the stem xylem sap in oilseed rape (Brassica napus). Ammonium translocation in the xylem may provide ammonium for primary assimilation in the shoot, where it can be assimilated by GS.

\section{Ammonium originating from $\mathrm{N}_{2}$ reduction}

The enzyme nitrogenase catalyses the reduction of $\mathrm{N}_{2}$ to ammonium. This oxygen-sensitive enzyme is not present in plants, but associations between nitrogen-fixing microorganisms and plants can be established. The production of ammonium that occurs either within the plant's tissues or in specialized organs called nodules can significantly contribute to plant nitrogen nutrition. Cytosolic GS assimilates ammonium from the three major types of nitrogen-fixing symbiotic association involving plants and either Rhizobium, actinomycetes, such as Frankia, or cyanobacteria (Rai et al., 2000). In some species, a specific cytosolic GS isoenzyme is induced in nitrogen-fixing root nodules (Lara et al., 1983; Forde et al., 1989), whereas, in others, cytosolic GS already present is involved (Carvalho et al., 2000a). In alfalfa, the level of transcripts for a nodulespecific GS gene was dependent on the nodule nitrogen-fixing capacity (Vance et al., 1994). In some species, cytosolic GS is present in infected plant cells within the nodule, where it assimilates ammonium that is locally released from the nitrogenase-mediated reduction of atmospheric $\mathrm{N}_{2}$ (Oaks, 1992, Carvalho et al., 2000b). By contrast, in Frankia-infected Dastica glomerata plants, GS is highly abundant in uninfected nodule cortical tissues at a distance from the $\mathrm{N}_{2}$ reduction site (Berry et al., 2004). In the nodules, cytosolic GS is posttranslationally regulated by phosphorylation in response to nitrogen fixation (Lima et al., 2006). Cytosolic GS also assimilates ammonium produced by endophytic diazotrophs colonizing the internal parts of some plants, such as sugarcane, without establishing symbiotic relationships (Nogueira et al., 2005).

\section{Ammonium from nitrate reduction}

Some plant species show a preference for root nitrate assimilation, whereas, for many others, this occurs primarily in the leaf (Andrews, 1986; Wallace, 1986; Woodall \& Forde, 1996). Together with the possibility of ammonium translocation to the shoot, this difference suggests that, depending on the plant species, primary nitrogen assimilation can occur in the roots and/or shoots. Nitrate reduction is compartmentalized between the cytosol, where nitrate reductase is active, and the plastid, where nitrite reductase produces ammonium. In barley roots, where cytosolic GS is the major form, GS activity was higher in nitrate-fed plants, without any corresponding increase in polypeptide abundance (measured by western blot and immunolabelling) (Peat \& Tobin, 1996). This higher activity suggested that cytosolic GS is involved in the assimilation of ammonium originating from nitrate reduction in the roots (Peat \& Tobin, 1996; Tobin \& Yamaya, 2001), and that post-translational regulation of cytosolic GS occurs in response to nitrate treatment. GS could be detected by immunolocalization in the plastids of young barley root; however, plastidic GS is a minor form in barley root and could not be detected (by western blot) in whole-root protein extracts (Peat \& Tobin, 1996). Woodall \& Forde (1996) have suggested that the presence of plastidic GS in the roots could be the result of an adaptation of legume species to nitrate-rich temperate soils.

In young and mature photosynthesizing leaves, both chloroplastic and cytosolic GS proteins and activities have been measured (McNally et al., 1983; McNally \& Hirel, 1983; Yamaya \& Oaks, 1988; Sakakibara et al., 1992; Becker et al., 2000; Habash et al., 2001; Tobin \& Yamaya, 2001), thus confirming that they are both assimilating ammonium. The proportion of chloroplastic to cytosolic isoforms differs, depending on the species studied (McNally et al., 1983). Although the levels of cytosolic GS and GS2 were equal in maize bundle-sheath cells, the level of cytosolic GS protein was 1.8-fold higher than that of GS2 protein in mesophyll cells (Becker et al., 1993). In these cells, the GS1-3 isoenzyme is expressed constitutively, suggesting that it assimilates ammonium originating from nitrate reduction (Martin et al., 2006).

For annual $\mathrm{C}_{3}$ grasses, such as wheat, rice or barley, cytosolic GS is less abundant in the leaf. Nevertheless, it is an important component, considering its vascular cell localization and specific physiological functions, as discussed below. A study of barley mutants deficient in GS2 showed a normal phenotype and no nitrogen deficiency when grown under nonphotorespiratory conditions (Wallsgrove et al., 1987; Leegood et al., 1995), suggesting that cytosolic GS is involved in primary nitrogen 
assimilation. The cellular localization of cytosolic GS in vascular bundles, particularly in the phloem and xylem parenchyma cells of the leaves and stem, in $\mathrm{C}_{3}$ species (Kamachi et al., 1992; Carvalho et al., 2000b) suggests that ammonium is also assimilated in these cells. Ammonium may originate from local sources or be transported from mesophyll cells, where nitrate is reduced, to the vascular cells, where most of the cytosolic GS is localized.

\section{Cytosolic GS assimilates ammonium from nitrogen remobilization}

Nitrogen remobilization from protein breakdown is the main source of nitrogen for grain filling in annual species, supplying c. $80 \%$ of the total nitrogen in rice grains (Mae \& Ohira, 1981; Tabuchi et al., 2007). A number of studies have suggested a role for cytosolic GS in the remobilization of the inorganic form of nitrogen from senescing leaves for grain filling in annual species. First, the localization of cytosolic GS in the vascular tissues and the developmental regulation of cytosolic GS suggest that it is important for nitrogen remobilization. Subsequently, rice and maize mutant studies, as well as QTL analyses, have shown that cytosolic GS is necessary for grain filling (Hirel et al., 2001; Obara et al., 2001, 2004; Habash et al., 2007; for a recent review, see Hirel et al., 2007b).

\section{Cytosolic GS cellular localization indicates a role in the transport of nitrogen}

In both $\mathrm{C}_{3}$ and $\mathrm{C}_{4}$ species, cytosolic $\mathrm{GS}$ is located in vascular bundles (Sakurai et al., 1996; Kichey et al., 2005; Martin et al., 2006). Furthermore, recent studies have shown that cytosolic GS is located in intermediary cells, where nitrogen is exchanged between different cell types, such as the primary pit fields connecting the mestome sheath cells and the neighbouring parenchyma and vascular cells in wheat leaves (Kichey et al., 2005), and the core linking the mesophyll and vascular bundle cells in sugarcane leaves (Nogueira et al., 2005). Cytosolic GS protein accumulates in the mesophyll cells of tomato (Lycopersicon esculentum) plants in response to stress, such as pathogen attack (Pérez-García et al., 1998b), or senescence (Brugière et al., 1999, 2000; Kichey et al., 2005), suggesting a role for this isoform in the reassimilation of the nitrogen released during the disassembly of the photosynthetic apparatus.

\section{Cytosolic GS assimilates ammonium in a developmentally controlled manner}

Leaf GS isoenzymes are regulated in a developmentally controlled manner during vegetative and reproductive plant growth stages (Tobin et al., 1985; Kamachi et al., 1991; Sakurai et al., 1996; Pérez-Rodríguez \& Valpuesta, 1996; Finnemann
\& Schjoerring, 2000; Habash et al., 2001; Bernard et al., 2008), and particularly through senescence (Buchanan-Wollaston et al., 2003). Studies in many species have noted a decline in abundance of mRNA, protein and activity of GS2 in senescing leaves, coinciding with an increase in abundance of cytosolic GS (Finnemann \& Schjoerring, 2000; Masclaux et al., 2000; Habash et al., 2001; Bernard et al., 2008). In wheat, two cytosolic GS genes are regulated differently during leaf senescence: GS1 transcript abundance increases from anthesis, whereas $G S r$ transcript levels remain steady until a late stage of development (Bernard et al., 2008). In maize, GS2 is less abundant in the leaves, whereas cytosolic GS is present throughout leaf development and under varying nitrogen levels. Several GS isoenzymes are necessary to maintain a high level of cytosolic GS activity in the leaves, with $g \ln 3$ being up-regulated in senescing maize leaves (Hirel et al., 2005). Finnemann \& Schjoerring (2000) suggested that phosphorylation and binding to 14-3-3 proteins was also a possible means by which to regulate cytosolic GS during senescence, mainly by increasing enzyme stability.

Leaf senescence involves the highly coordinated recycling of nitrogen (Hortensteiner \& Feller, 2002), with cytosolic GS assimilating ammonium from the catabolism of amino acids. Interestingly, GDH activity increases during senescence (Masclaux et al., 2000), where it mostly functions in the deamination direction, thus producing ammonium in the mitochondria. This activity also provides carbon in the form of 2oxoglutarate to the tricarboxylic acid cycle, and is especially important for carbon-starved plants (Miyashita \& Good, 2008).

In perennial plants, seasonal nitrogen cycling is an important process of remobilization and transport of nitrogen compounds from senescing tissues towards overwintering storage tissues in the autumn, and reassimilation from the storage tissues during the spring flush (Cooke \& Weih, 2005). A study carried out in poplar suggests that one cytosolic GS gene is up-regulated early on during autumn senescence, and that its transcript level subsequently declines (Andersson et al., 2004). Thus far, the role of GS in the spring remobilization of nitrogen has not been investigated.

\section{Cytosolic GS remobilizes nitrogen for grain filling}

Significant correlations were obtained between grain number/ size and a locus for cytosolic GS protein content in rice (OsGln1;1; Yamaya et al., 2002; Obara et al., 2004). In maize, coincidences of QTLs were found for GS activity, cytosolic GS locus ( $g \ln 1)$ and grain yield (Hirel et al., 2001, 2007b; Gallais \& Hirel, 2004). In wheat, GS activity (chloroplastic and cytosolic isoforms) was shown to be positively correlated with grain and stem nitrogen content (Habash et al., 2007). These studies highlight the importance of cytosolic GS genes in determining several aspects of nitrogen use traits in cereal crops, with potential implications for breeding and agriculture (for a review, see Andrews et al., 2004; Hirel et al., 2007b). 
The most compelling evidence for the role of cytosolic GS in nitrogen remobilization for grain filling has come from recent studies of mutants deficient in leaf cytosolic GS in rice and maize (Tabuchi et al., 2005; Martin et al., 2006). In rice, the homozygous lines of three $O s G S 1 ; 1$-knockout mutants showed a decline in cytosolic GS enzyme activity (Tabuchi et al., 2005). The phenotypes of these mutants, retardation in growth rate, reduced spikelet weight and number, and reduced fertility, strongly suggest a role for $O s G S 1 ; 1$ in grain filling in rice. In maize, two mutants were identified with the maize Mutator $(M u)$ system, showing an insertion in either $G \ln 1-3$ or $G \ln 1-4$, and a third double mutant was constructed with $M u$ inserted in both genes (Martin et al., 2006). The two single mutants displayed specific phenotypes, with the $g \ln 1-4$ mutant exhibiting a reduced kernel size and the $g \ln 1-3$ mutant a reduced kernel number. As opposed to the phenotype seen in rice, the loss of cytosolic GS activity in the leaves had no effect on the shoot dry weight of the three maize mutants, including the double mutant.

In addition, cytosolic GS assimilates ammonium in sink tissues, as suggested by the strong expression of the cytosolic GS gene in developing maize seeds (Rastogi et al., 1998), and the fact that it is the major GS isoform in maize immature tassels, cobs and husks (Muhitch, 2003). In these tissues, asparaginase is a possible source of ammonium because it catabolizes asparagine (for a review, see Lea et al., 2007).

\section{Nitrogen remobilization during germination}

During germination, the growth of plantlets is dependent on the release of nutrients from the seed storage compounds. Cytosolic GS has been detected in different parts of the embryos of both starch-accumulating seeds, with a protein content of $10-15 \%$ of total grain dry weight (Shewry \& Halford, 2002), and legumes, which tend to accumulate a larger amount of storage proteins (Duranti \& Gius, 1997). Genetic studies in maize (Limami et al., 2002) showed the co-localization of a QTL for a high rate of germination with the Gln 1-3 structural gene. This study also suggested that high levels of GS activity in the germinating seed could lead to faster germination. Several cytosolic GS genes are involved in germination and show specific cellular expression (Cantón et al., 1999, Ávila et al., 2001; Glevarec et al., 2004; Rodriguez et al., 2006). Gómez-Maldonado et al. (2004a) proposed that hormonal control, particularly by gibberellic acid, is part of the regulation of cytosolic GS in the early stages of pine development.

\section{Ammonium assimilation during lignin synthesis}

The enzyme PAL catalyses the first step of the phenylpropanoid pathway in deaminating phenylalanine, with the subsequent release of ammonium. To maintain an efficient nitrogen economy, this ammonium must be reassimilated back into amino acids. This is performed by cytosolic GS, which has been shown to co-localize and co-express with PAL in vascular xylem cells (Suárez et al., 2002; Cantón et al., 2005). Studies in rice have also demonstrated the co-localization of cytosolic GS and PAL in the vascular cells of immature leaves (Sakurai et al., 2001). Conifers invest large amounts of carbon in the phenylpropanoid pathway for the synthesis of lignin (Cánovas et al., 2007). The cis-acting elements found in the promoter region of the pine $G S 1 b$ gene showed a similarity to those of the promoter of the bean PAL2 gene (GómezMaldonado et al., 2004b). Further analyses demonstrated an interaction between MYB transcription factors and the cis-acting elements, suggesting that this was a possible way of co-regulating lignin synthesis and nitrogen reassimilation in pine.

\section{The role of cytosolic GS in nitrogen assimilation and recycling is important for plant growth and seed production}

The significance of cytosolic GS in plant growth and development has been emphasized in studies using forward and reverse genetic approaches. A variety of plant species have been modified to overexpress cytosolic GS, following different strategies in terms of promoter and transgene selection. Although the outcomes of these studies have been variable, they imply that cytosolic GS is important for efficient nitrogen assimilation, plant growth and biomass accumulation. Tobacco and poplar plants expressing a transgenic GS1 under the control of a constitutive promoter showed a decrease in ammonium content in the leaves, indicating a higher rate of nitrogen assimilation (Oliveira et al., 2002; Man et al., 2005). An increase in total leaf soluble protein content was noted in GS1-overexpressing poplar plants (Gallardo et al., 1999; Fu et al., 2003; Jing et al., 2004), tobacco (Temple et al., 1993; Oliveira et al., 2002) and L. japonicus (Ortega et al., 2004). The effects of $G S 1$ overexpression were also noticed in transgenic tobacco plants, particularly as these were able to maintain high photosynthetic rates even under limiting nitrogen conditions (Fuentes et al., 2001). The effects of increased cytosolic GS on plant growth were particularly dramatic in poplar plants overexpressing a pine $G S 1$ gene. In these plants, vegetative growth was increased, leading to an increase in height in both glasshouse and field experiments (Gallardo et al., 1999; Jing et al., 2004). A similar result was obtained with L. corniculatus plants overexpressing a soybean GS1 gene, which senesced earlier than control plants (Vincent et al., 1997).

The impact of GS overexpression on plant biomass is variable, depending on the species studied and the growth conditions. Tobacco and L. japonicus plants overexpressing a GS1 gene under the control of a constitutive promoter showed an increase in total plant fresh and dry weight (Oliveira et al., 2002; Ortega et al., 2004). An increase in dry weight was observed in the roots and grains of wheat plants overexpressing 
cytosolic GS, specifically in the leaves, ultimately leading to an increased grain nitrogen yield (Habash et al., 2001). These studies thereby demonstrate that the manipulation of GS produces a range of phenotypes affecting growth, development and nitrogen assimilation. To focus and target the modulation more precisely necessitates cell-specific and developmentally specific promoters for transformation. This remains an open field for research.

\section{Cytosolic GS response to varying environmental conditions and plant nitrogen status}

Cytosolic GS responds to nitrogen availability in the external medium, plant nitrogen status (ratio of glutamine to glutamate), light/dark and the presence of abiotic and biotic stressors. Thus far, it has been difficult to establish a global model of GS response to variation in nitrogen availability in both roots and leaves. Although some cytosolic GS gene members are up-regulated by the addition of ammonium, some are down-regulated or do not respond (Sakakibara et al., 1996; Finnemann \& Schjoerring, 1999, Ishiyama et al., 2004b; Hirel et al., 2005). These discrepancies could be explained by differences between experimental procedures and/or by species variation in terms of response to nitrogen deficiency and variation in nitrogen sources. Differences in gene number among species could also lead to more complex response patterns in some species. Although most studies have focused on the response to severe nitrogen deficiency, few have examined the effect of steady-state nitrogen deficiency on nitrogen metabolism, which is more relevant to fieldgrown plants.

Variations in soil nitrogen availability, including the type of nitrogen source and amount, affect plant nitrogen status and the direct availability of ammonium for assimilation at both cellular and organ levels. In nitrogen-repleted oilseed rape, the accumulation of cytosolic GS gene transcripts declined in the roots, leading to enhanced translocation of ammonium to the shoots (Finnemann \& Schjoerring, 1999). Ammonium itself regulates cytosolic GS genes at the transcriptional level (Hirel et al., 1987; Kozaki et al., 1992; Sukanya et al., 1994). In soybean, the cooperation of three distinct promoter regions is necessary for ammonium-stimulated expression of the gene (Tercé-Laforgue et al., 1999). The interaction among these three regions may be facilitated by an HMG A-like protein that binds to the proximal and distal promoter regions of the soybean GS15 gene (Reisdorf-Cren et al., 2002). Plant nitrogen status also alters the transcriptional regulation of cytosolic GS genes by ammonium in the roots (Sonoda et al., 2003; Ishiyama et al., 2004c).

Transcript stability is another means of cytosolic GS regulation in response to nitrogen nutrition (Ortega et al., 2006). However, it is not clear whether plant nitrogen status or nitrate molecules interact with the cis-acting element at the $3^{\prime}$ end of the GS1 transcripts. An increased level of cytosolic
GS polypeptide has been measured in the leaves of $A$. thaliana Wassileskija accession plants grown under nitrogen-deficient conditions, probably to assimilate ammonium from the catabolism of protein (Lemaitre et al., 2008). The capacity of plants to tolerate low nitrogen availability may also be linked to their tolerance to other stresses. For example, Thellungiella halophila, a relative of $A$. thaliana, has been shown to be tolerant to salt stress and nitrogen limitation, because of its higher nitrate uptake and assimilation (Kant et al., 2008).

In response to drought or salt stress, the abundance of the GS2 polypeptide and its activity decline, whereas cytosolic GS tends to increase or maintain the same level in the leaves (Bauer et al., 1997; Lutts et al., 1999; Santos et al., 2004; Martinelli et al., 2007; D. Z. Habash et al., unpublished). Transgenic poplar plants expressing a pine cytosolic GS gene show enhanced water stress resistance compared with controls (El-Khatib et al., 2004). These results suggest that GS overexpression leads to an increased photorespiratory activity, thus providing a protective sink for electrons from photosynthetic reaction centres (although the photoprotective role of photorespiration remains controversial). The response of GS to drought or salt stress in the roots is less clear, with studies in rice seedlings and potatoes showing a decline in GS total activity in response to salt stress (Lutts et al., 1999; Teixeira \& Pereira, 2007), and studies in rice and sunflower showing an increased cytosolic GS polypeptide abundance and activity (Santos et al., 2004; Yan et al., 2005). The response of cytosolic GS to osmotic stress is related to the reassimilation of nitrogen from increased amino acid catabolism, and is necessary for the production of proline (Brugière et al., 1999).

Some evidence exists for the induction of either cytosolic GS genes or novel forms of cytosolic GS proteins in infected leaf cells in plants under pathogen attack (Pérez-García et al., 1995, 1998a,b; Oléa et al., 2004; Pageau et al., 2006; Tavernier et al., 2007). Pageau et al. (2006) showed that GS1 was upregulated in tobacco leaves in response to viral and bacterial attacks, especially when an incompatible reaction was triggered. However, this induction did not depend on a hypersensitive response induction, suggesting that $G S 1$ shows the same pattern of expression as an early plant defence gene. Similarly, Tavernier et al. (2007) showed that Gln- $\alpha$ from P. vulgaris was up-regulated in response to pathogenic and nonpathogenic strains of fungus, again implying that it responds in the same manner as an early-response defence gene. In the latter study, Tavernier et al. (2007) also showed that the expression of $G l n-\alpha$ followed that of PAL3, perhaps indicating that cytosolic GS was there to reassimilate ammonium from PAL activity. This up-regulation of $G l n-\alpha$ was also accompanied by an increase in cytosolic GS polypeptide abundance, but an overall decline in activity, mainly resulting from the decline in chloroplastic GS. The response of cytosolic GS to abiotic and biotic stresses occurred mainly at the transcript abundance levels. However, it is unclear whether an increase in transcription occurs, or whether mRNA transcripts are more stable. 


\section{GS is key to adjusting nitrogen assimilation and recycling in response to varied environmental conditions}

The coordination and optimal functioning of the metabolic pathways for nitrogen and carbon assimilation in plants are critical in determining plant growth and, ultimately, biomass accumulation (Krapp et al., 2005). GS is a necessary enzyme for nitrogen metabolism, as it catalyses the assimilation of all inorganic nitrogen incorporated into organic compounds, such as proteins and nucleic acids. This reaction is coupled to the formation of glutamate by GOGAT as part of the GS/ GOGAT cycle. Although Ferredoxin-GOGAT plays a critical part in the reassimilation of ammonium released by glycine decarboxylase during photorespiration, NADH-GOGAT assimilates ammonium from both primary and secondary sources during nitrogen remobilization (Lea \& Miflin, 2003).

The fundamental role of GS within nitrogen metabolism may explain its ancient origins and justify its presence in both eukaryotes and prokaryotes. In plants, different GS genes have evolved that assimilate ammonium from various sources in different cells and tissues. Cytosolic GS is of particular interest, because it is encoded by many genes and holds many functions within the plant. Genetic modification of a cytosolic GS gene via mutation or transgenesis has led to alterations in whole plant metabolism and phenotypes, particularly plant and seed biomass. However, these effects are not always consistent between studies, probably because of the complex regulation of GS. Continuous research demonstrates that cytosolic GS genes, transcripts and proteins are also responsive to both the plant status and environmental cues. Overall, this suggests that GS may constitute a regulatory point at which environmental signals are integrated and translated into a plant response in terms of growth and seed production.

Although our understanding of cytosolic GS has greatly increased since its discovery, many questions remain: in particular, certain aspects of its regulation are still not fully understood. However, a further understanding of the molecular basis for plant nitrogen uptake/assimilation and its regulation is critical for understanding plant response to fluctuating environmental conditions.

\section{Acknowledgements}

We thank Professor David Ackerly (University of California, Berkeley), Professor Peter Lea (Lancaster University) and Professor Christer Jansson (Lawrence Berkeley National Laboratory) for their careful reading of the manuscript and helpful comments. S.M.B. is supported by the Climate Change Research Division, Office of Science, US Department of Energy under Contract No. DE-AC02-05CH11231. D.Z.H. is supported by Rothamsted Research, which is grant aided by the Biotechnology and Biological Sciences Research Council of the UK.

\section{References}

Almassy RJ, Janson CA, Hamlin R, Xuong NH, Eisenberg D. 1986. Novel subunit-subunit interactions in the structure of glutamine synthetase. Nature 323: 304-309.

Andersson A, Keskitalo J, Sjodin A, Bhalerao R, Sterky F, Wissel K, Tandre K, Aspeborg H, Moyle R, Ohmiya Y et al. 2004. A transcriptional timetable of autumn senescence. Genome Biology 5: R24.

Andrews M. 1986. The partitioning of nitrate assimilation between root and shoot of higher plants. Plant, Cell \& Environment 9: 511-519.

Andrews M, Lea PJ, Raven JA, Lindsey K. 2004. Can genetic manipulation of plant nitrogen assimilation enzymes result in increased crop yield and greater N-use efficiency? An assessment. Annals of Applied Biology 145: $25-40$.

Ávila C, Cantón FR, Barnestein P, Suárez MF, Marraccini P, Rey M, Humara JM, Ordas R, Cánovas FM. 2001. The promoter of a cytosolic glutamine synthetase gene from the conifer Pinus sylvestris is active in cotyledons of germinating seeds and light-regulated in transgenic Arabidopsis thaliana. Physiologia Plantarum 112: 388-396.

Bardgett RD. 2005. The biology of soil: a community and ecosystem approach. Oxford, UK: Oxford University Press.

Bauer D, Biehler K, Fock H, Carrayol E, Hirel B, Migge A, Becker TW. 1997. A role for cytosolic glutamine synthetase in the remobilization of leaf nitrogen during water stress in tomato. Physiologia Plantarum 99: 241-248.

Becker TW, Carrayol E, Hirel B. 2000. Glutamine synthetase and glutamate dehydrogenase isoforms in maize leaves: localization, relative proportion and their role in ammonium assimilation or nitrogen transport. Planta 211: 800-806.

Becker TW, Perrotrechenmann C, Suzuki A, Hirel B. 1993. Subcellular and immunocytochemical localization of the enzymes involved in ammonia assimilation in mesophyll and bundle-sheath cells of maize leaves. Planta 191: 129-136.

Bernard SM. 2005. Manipulating the expression of glutamine synthetase in wheat (Triticum aestivum). PhD thesis. Lancaster, UK: Lancaster University.

Bernard SM, Moller ALB, Dionisio G, Kichey T, Jahn TP, Dubois F, Baudo M, Lopes MS, Tercé-Laforgue T, Foyer CH et al. 2008. Gene expression, cellular localisation and function of glutamine synthetase isozymes in wheat (Triticum aestivum L.). Plant Molecular Biology 67: 89-105.

Berry AM, Murphy TM, Okubara PA, Jacobsen KR, Swensen SM, Pawlowski K. 2004. Novel expression pattern of cytosolic glutamine synthetase in nitrogen-fixing root nodules of the actinorhizal host, Datisca glomerata. Plant Physiology 135: 1849-1862.

Betti M, Arcondeguy T, Marquez AJ. 2006. Molecular analysis of two mutants from Lotus japonicus deficient in plastidic glutamine synthetase: functional properties of purified GLN2 enzymes. Planta 224: 1068-1079.

Biesiadka J, Legocki AB. 1997. Evolution of the glutamine synthetase gene in plants. Plant Science 128: 51-58.

Britto DT, Kronzucker HJ. 2005. Plant nitrogen transport and its regulation in changing soil environments. Journal of Crop Improvement 15: $1-23$

Brugière N, Dubois F, Limami AM, Lelandais M, Roux Y, Sangwan RS, Hirel B. 1999. Glutamine synthetase in the phloem plays a major role in controlling proline production. Plant Cell 11: 1995-2011.

Brugière N, Dubois F, Masclaux C, Sangwan RS, Hirel B. 2000. Immunolocalization of glutamine synthetase in senescing tobacco (Nicotiana tabacum L.) leaves suggests that ammonia assimilation is progressively shifted to the mesophyll cytosol. Planta 211: 519-527.

Buchanan-Wollaston V, Earl S, Harrison E, Mathas E, Navabpour S, Page T, Pink D. 2003. The molecular analysis of leaf senescence - a genomics approach. Plant Biotechnology Journal 1: 3-22.

Buscot F, Munch JC, Charcosset JY, Gardes M, Nehls U, Hampp R. 2000. Recent advances in exploring physiology and biodiversity of 
ectomycorrhizas highlight the functioning of these symbioses in ecosystems. Fems Microbiology Reviews 24: 601-614.

Cánovas FM, Ávila C, Cantón FR, Canas RA, de la Torre F. 2007. Ammonium assimilation and amino acid metabolism in conifers. Journal of Experimental Botany 58: 2307-2318.

Cantón FR, Suarez MF, Cánovas FM. 2005. Molecular aspects of nitrogen mobilization and recycling in trees. Photosynthesis Research 83: 265-278.

Cantón FR, Suarez MF, Jose-Estanyol M, Cánovas FM. 1999. Expression analysis of a cytosolic glutamine synthetase gene in cotyledons of Scots pine seedlings: developmental, light regulation and spatial distribution of specific transcripts. Plant Molecular Biology 40: 623-634.

Carvalho H, Lescure N, de Billy F, Chabaud M, Lima L, Salema R, Cullimore J. 2000a. Cellular expression and regulation of the Medicago truncatula cytosolic glutamine synthetase genes in root nodules. Plant Molecular Biology 42: 741-756.

Carvalho H, Lima L, Lescure N, Camut S, Salema R, Cullimore J. 2000 b. Differential expression of the two cytosolic glutamine synthetase genes in various organs of Medicago truncatula. Plant Science 159: 301-312.

Clemente MT, Marquez AJ. 1999a. Functional importance of asp 56 from the alpha-polypeptide of Phaseolus vulgaris glutamine synthetase - an essential residue for transferase but not for biosynthetic enzyme activity. European Journal of Biochemistry 264: 453-460.

Clemente MT, Marquez AJ. 1999b. Site-directed mutagenesis of glu-297 from the alpha-polypeptide of Phaseolus vulgaris glutamine synthetase alters kinetic and structural properties and confers resistance to L-methionine sulfoximine. Plant Molecular Biology 40: 835-845.

Clemente MT, Marquez AJ. 2000. Site-directed mutagenesis of cys- 92 from the alpha-polypeptide of Phaseolus vulgaris glutamine synthetase reveals that this highly conserved residue is not essential for enzyme activity but it is involved in thermal stability. Plant Science 154: 189-197.

Cooke JEK, Weih M. 2005. Nitrogen storage and seasonal nitrogen cycling in Populus: bridging molecular physiology and ecophysiology. New Phytologist 167: 19-30.

Cren M, Hirel B. 1999. Glutamine synthetase in higher plants: regulation of gene and protein expression from the organ to the cell. Plant and Cell Physiology 40: 1187-1193.

Cruz C, Bio AFM, Dominguez-Valdivia MD, Aparicio-Tejo PM, Lamsfus C, Martins-Loucao MA. 2006. How does glutamine synthetase activity determine plant tolerance to ammonium? Planta 223: 1068-1080.

Doyle JJ. 1991. Evolution of higher plant glutamine synthetase genes tissue specificity as a criterion for predicting orthology. Molecular Biology and Evolution 8: 366-377.

Duranti M, Gius C. 1997. Legume seeds: protein content and nutritional value. Field Crops Research 53: 31-45.

El-Khatib RT, Hamerlynck EP, Gallardo F, Kirby EG. 2004. Transgenic poplar characterized by ectopic expression of a pine cytosolic glutamine synthetase gene exhibits enhanced tolerance to water stress. Tree Physiology 24: 729-736.

Fei HM, Chaillou S, Hirel B, Mahon JD, Vessey JK. 2003. Overexpression of a soybean cytosolic glutamine synthetase gene linked to organ-specific promoters in pea plants grown in different concentrations of nitrate. Planta 216: 467-474.

Finnemann J, Schjoerring JK. 1999. Translocation of $\mathrm{NH}_{4}^{+}$in oilseed rape plants in relation to glutamine synthetase isogene expression and activity. Physiologia Plantarum 105: 469-477.

Finnemann J, Schjoerring JK. 2000. Post-translational regulation of cytosolic glutamine synthetase by reversible phosphorylation and 14-3-3 protein interaction. Plant Journal 24: 171-181.

Forde BG, Cullimore JV. 1989. The molecular biology of glutamine synthetase in higher plants. Oxford Surveys of Plant Molecular and Cell Biology 6: 247-296.

Forde BG, Day HM, Turton JF, Shen WJ, Cullimore JV, Oliver JE. 1989. Two glutamine-synthetase genes from Phaseolus vulgaris L. display contrasting developmental and spatial patterns of expression in transgenic Lotus corniculatus plants. Plant Cell 1: 391-401.
Forde BG, Lea PJ. 2007. Glutamate in plants: metabolism, regulation and signalling. Journal of Experimental Biology 58: 2339-2358.

Fu J, Sampalo R, Gallardo F, Cánovas FM, Kirby EG. 2003. Assembly of a cytosolic pine glutamine synthetase holoenzyme in leaves of transgenic poplar leads to enhanced vegetative growth in young plants. Plant, Cell \& Environment 26: 411-418.

Fuentes SI, Allen DJ, Ortiz-Lopez A, Hernandez G. 2001. Over-expression of cytosolic glutamine synthetase increases photosynthesis and growth at low nitrogen concentrations. Journal of Experimental Botany 52: $1071-1081$.

Gallais A, Hirel B. 2004. An approach to the genetics of nitrogen use efficiency in maize. Journal of Experimental Botany 55: 295-306.

Gallardo F, Fu JM, Canton FR, Garcia-Gutierrez A, Cánovas FM, Kirby EG. 1999. Expression of a conifer glutamine synthetase gene in transgenic poplar. Planta 210: 19-26.

García-Dominguez M, Reyes JC, Florencio FJ. 1997. Purification and characterization of a new type of glutamine synthetase from cyanobacteria. European Journal of Biochemistry 244: 258-264.

Garcia-Gutierrez A, Dubois F, Canton FR, Gallardo F, Sangwan RS, Canovas FM. 1998. Two different modes of early development and nitrogen assimilation in gymnosperm seedlings. Plant Journal 13: 187-199.

Glass ADM, Britto DT, Kaiser BN, Kinghorn JR, Kronzucker HJ, Kumar A, Okamoto M, Rawat S, Siddiqi MY, Unkles SE et al. 2002. The regulation of nitrate and ammonium transport systems in plants. Journal of Experimental Botany 53: 855-864.

Glevarec G, Bouton S, Jaspard E, Riou MT, Cliquet JB, Suzuki A, Limami AM. 2004. Respective roles of the glutamine synthetase/glutamate synthase cycle and glutamate dehydrogenase in ammonium and amino acid metabolism during germination and post-germinative growth in the model legume Medicago truncatula. Planta 219: 286-297.

Gómez-Maldonado J, Ávila C, de la Torre F, Canas R, Cánovas FM, Campbell MM. 2004a. Functional interactions between a glutamine synthetase promoter and MYB proteins. Plant Journal 39: 513-526.

Gómez-Maldonado J, Cánovas FM, Ávila C. 2004b. Molecular analysis of the $5^{\prime}$-upstream region of a gibberellin-inducible cytosolic glutamine synthetase gene (GS1b) expressed in pine vascular tissue. Planta 218: 1036-1045.

Habash DZ, Bernard S, Schondelmaier J, Weyen J, Quarrie SA. 2007. The genetics of nitrogen use in hexaploid wheat: $\mathrm{N}$ utilisation, development and yield. Theoretical and Applied Genetics 114: 403-419.

Habash DZ, Massiah AJ, Rong HL, Wallsgrove RM, Leigh RA. 2001. The role of cytosolic glutamine synthetase in wheat. Annals of Applied Biology 138: 83-89.

Hayashi H, Chino M. 1990. Chemical-composition of phloem sap from the uppermost internode of the rice plant. Plant and Cell Physiology 31: $247-251$.

He XH, Critchley C, Bledsoe C. 2003. Nitrogen transfer within and between plants through common mycorrhizal networks (cmns). Critical Reviews in Plant Sciences 22: 531-567.

Hill RT, Parker JR, Goodman HJK, Jones DT, Woods DR. 1989. Molecular analysis of a novel glutamine synthetase of the anaerobe Bacteroides fragilis. Journal of General Microbiology 135: 3271-3279.

Hirel B, Bertin P, Quilleré I, Bourdoncle W, Attagnant C, Dellay C, Gouy A, Cadiou S, Retailliau C, Falque M et al. 2001. Towards a better understanding of the genetic and physiological basis for nitrogen use efficiency in maize. Plant Physiology 125: 1258-1270.

Hirel B, Bouet C, King B, Layzell D, Jacobs F, Verma DPS. 1987. Glutamine synthetase genes are regulated by ammonia provided externally or by symbiotic nitrogen fixation. EMBO Journal 6: 1167-1171.

Hirel B, Chardon F, Durand J. 2007a. The contribution of molecular physiology to the improvement of nitrogen use efficiency. Journal of Crop Science and Biotechnology 10: 123-132.

Hirel B, Le Gouis J, Ney B, Gallais A. 2007b. The challenge of improving nitrogen use efficiency in crop plants: towards a more central role for 
genetic variability and quantitative genetics within integrated approaches. Journal of Experimental Botany 58: 2369-2387.

Hirel B, Martin A, Tercé-Laforgue T, Gonzalez-Moro MB, Estavillo JM. 2005. Physiology of maize I: a comprehensive and integrated view of nitrogen metabolism in a $\mathrm{C}_{4}$ plant. Physiologia Plantarum 124: 167-177.

Hortensteiner S, Feller U. 2002. Nitrogen metabolism and remobilization during senescence. Journal of Experimental Botany 53: 927-937.

Ishiyama K, Inoue E, Tabuchi M, Yamaya T, Takahashi H. 2004 . Biochemical background and compartmentalized functions of cytosolic glutamine synthetase for active ammonium assimilation in rice roots. Plant and Cell Physiology 45: 1640-1647.

Ishiyama K, Inoue E, Watanabe-Takahashi A, Obara M, Yamaya T, Takahashi H. 2004b. Kinetic properties and ammonium-dependent regulation of cytosolic isoenzymes of glutamine synthetase in Arabidopsis. Journal of Biological Chemistry 279: 16 598-16 605.

Ishiyama K, Inoue E, Watanabe-Takahashi A, Obara M, Yamaya T, Takahashi H. 2004c. Nitrogen-dependent regulation of cytosolic glutamine synthetase in Arabidopsis roots. Plant and Cell Physiology 45: S98-S98.

Ishiyama K, Kojima S, Takahashi H, Hayakawa T, Yamaya T. 2003. Cell type distinct accumulations of mRNA and protein for NADH-dependent glutamate synthase in rice roots in response to the supply of $\mathrm{NH}_{4}^{+}$. Plant Physiology and Biochemistry 41: 643-647.

Jing ZP, Gallardo F, Pascual MB, Sampalo R, Romero J, de Navarra AT, Cánovas FM. 2004. Improved growth in a field trial of transgenic hybrid poplar overexpressing glutamine synthetase. New Phytologist 164: 137-145.

Kamachi K, Yamaya T, Hayakawa T, Mae T, Ojima K. 1992. Vascular bundle-specific localization of cytosolic glutamine synthetase in rice leaves. Plant Physiology 99: 1481-1486.

Kamachi K, Yamaya T, Mae T, Ojima K. 1991. A role for glutamine synthetase in the remobilization of leaf nitrogen during natural senescence in rice leaves. Plant Physiology 96: 411-417.

Kant S, Bi YM, Weretilnyk E, Barak S, Rothstein SJ. 2008. The Arabidopsis halophytic relative Thellungiella halophila tolerates nitrogen-limiting conditions by maintaining growth, nitrogen uptake, and assimilation. Plant Physiology 147: 1168-1180.

Keys AJ, Bird IF, Cornelius MJ, Lea PJ, Wallsgrove RM, Miflin BJ. 1978. Photorespiratory nitrogen cycle. Nature, 275: 741-742.

Kichey T, Le Gouis J, Sangwan B, Hirel B, Dubois F. 2005. Changes in the cellular and subcellular localization of glutamine synthetase and glutamate dehydrogenase during flag leaf senescence in wheat (Triticum aestivum L.). Plant and Cell Physiology 46: 964-974.

Kim HB, Kim SH, Lee H, Oh CJ, An CS. 2004. Molecular cloning of a cDNA encoding glutamine synthetase from root nodules of Elaeagnus umbellata. Journal of Plant Biology 47: 401-406.

Kozaki A, Sakamoto A, Takeba G. 1992. The promoter of the gene for plastidic glutamine synthetase (GS2) from rice is developmentally regulated and exhibits substrate-induced expression in transgenic tobacco plants. Plant and Cell Physiology 33: 233-238.

Krajewski WW, Jones TA, Mowbray SL. 2005. Structure of Mycobacterium tuberculosis glutamine synthetase in complex with a transition-state mimic provides functional insights. Proceedings of the National Academy of Sciences, USA 102: 10 499-10 504.

Krapp A, Saliba-Colombani V, Daniel-Vedele F. 2005. Analysis of C and $\mathrm{N}$ metabolisms and of $\mathrm{C} / \mathrm{N}$ interactions using quantitative genetics. Photosynthesis Research 83: 251-263.

Kumada Y, Benson DR, Hillemann D, Hosted TJ, Rochefort DA, Thompson CJ, Wohlleben W, Tateno Y. 1993. Evolution of the glutamine synthetase gene, one of the oldest existing and functioning genes. Proceedings of the National Academy of Sciences, USA 90: 3009-3013.

Lara M, Cullimore JV, Lea PJ, Miflin BJ, Johnston AWB, Lamb JW. 1983. Appearance of a novel form of plant glutamine synthetase during nodule development in Phaseolus vulgaris L. Planta 157: 254-258.
Lea PJ, Miflin BJ. 2003. Glutamate synthase and the synthesis of glutamate in plants. Plant Physiology and Biochemistry 41: 555-564.

Lea PJ, Sodek L, Parry MAJ, Shewry PR, Halford NG. 2007. Asparagine in plants. Annals of Applied Biology 150: 1-26.

Leegood RC, Lea PJ, Adcock MD, Hausler RE. 1995. The regulation and control of photorespiration. Journal of Experimental Botany 46: 1397-1414.

Lemaître T, Gaufichon L, Boutet-Mercey S, Christ A, Masclaux-Daubresse C. 2008. Enzymatic and metabolic diagnostic of nitrogen deficiency in Arabidopsis thaliana Wassileskija accession. Plant and Cell Physiology 49: 1056-1065.

Li MG, Villemur R, Hussey PJ, Silflow CD, Gantt JS, Snustad DP. 1993. Differential expression of 6 glutamine synthetase genes in Zea mays. Plant Molecular Biology 23: 401-407.

Lian XM, Xing YZ, Yan H, Xu CG, Li XH, Zhang QF. 2005. QTLs for low nitrogen tolerance at seedling stage identified using a recombinant inbred line population derived from an elite rice hybrid. Theoretical and Applied Genetics 112: 85-96.

Lima L, Seabra A, Melo P, Cullimore J, Carvalho H. 2006. Posttranslational regulation of cytosolic glutamine synthetase of Medicago truncatula. Journal of Experimental Botany 57: 2751-2761.

Limami A, Phillipson B, Ameziane R, Pernollet N, Jiang QJ, Poy R, Deleens E, Chaumont-Bonnet M, Gresshoff PM, Hirel B. 1999. Does root glutamine synthetase control plant biomass production in Lotus japonicus L.? Planta 209: 495-502.

Limami AM, Rouillon C, Glevarec G, Gallais A, Hirel B. 2002. Genetic and physiological analysis of germination efficiency in maize in relation to nitrogen metabolism reveals the importance of cytosolic glutamine synthetase. Plant Physiology 130: 1860-1870.

Lutts S, Majerus V, Kinet JM. 1999. $\mathrm{NaCl}$ effects on proline metabolism in rice (Oryza sativa) seedlings. Physiologia Plantarum 105: 450-458.

Mae T, Ohira K. 1981. The remobilization of nitrogen related to leaf growth and senescence in rice plants (Oryza sativa L.). Plant and Cell Physiology 22: 1067-1074.

Man HM, Boriel R, El-Khatib R, Kirby EG. 2005. Characterization of transgenic poplar with ectopic expression of pine cytosolic glutamine synthetase under conditions of varying nitrogen availability. New Phytologist 167: 31-39.

Martin A, Lee J, Kichey T, Gerentes D, Zivy M, Tatout C, Dubois F, Balliau T, Valot B, Davanture M et al. 2006. Two cytosolic glutamine synthetase isoforms of maize are specifically involved in the control of grain production. Plant Cell 18: 3252-3274.

Martinelli T, Whittaker A, Bochicchio A, Vazzana C, Suzuki A, Masclaux-Daubresse C. 2007. Amino acid pattern and glutamate metabolism during dehydration stress in the 'resurrection' plant Sporobolus stapfianus: a comparison between desiccation-sensitive and desiccation-tolerant leaves. Journal of Experimental Botany 58: 3037-3046.

Masclaux C, Valadier MH, Brugière N, Morot-Gaudry JF, Hirel B. 2000. Characterization of the sink/source transition in tobacco (Nicotiana tabacum L.) shoots in relation to nitrogen management and leaf senescence. Planta 211: 510-518.

Mathis R, Gamas P, Meyer Y, Cullimore JV. 2000. The presence of GSI-like genes in higher plants: support for the paralogous evolution of GSI and GSII genes. Journal of Molecular Evolution 50: 116-122.

Mattsson M, Schjoerring JK. 2003. Senescence-induced changes in apoplastic and bulk tissue ammonia concentrations of ryegrass leaves. New Phytologist 160: 489-499.

McNally S, Hirel B. 1983. Glutamine synthetase isoforms in higher plants. Physiologie Vegetale 21: 761-774.

McNally SF, Hirel B, Stewart GR. 1983. Nitrogen-metabolism in halophytes. 5. The occurrence of multiple forms of glutamine-synthetase in leaf tissue. New Phytologist 94: 47-56.

Miflin BJ, Habash DZ. 2002. The role of glutamine synthetase and 11 
improvement in the nitrogen utilization of crops. Journal of Experimental Botany 53: 979-987.

Miller AJ, Fan XR, Orsel M, Smith SJ, Wells DM. 2007. Nitrate transport and signalling. Journal of Experimental Botany 58: 2297-2306.

Miyashita Y, Good AG. 2008. NAD(H)-dependent glutamate dehydrogenase is essential for the survival of Arabidopsis thaliana during dark-induced carbon starvation. Journal of Experimental Botany 59 : 667-680.

Muhitch MJ. 2003. Distribution of the glutamine synthetase isozyme $\mathrm{GS}_{\mathrm{p} 1}$ in maize (Zea mays). Journal of Plant Physiology 160: 601-605.

Nogueira ED, Olivares FL, Japiassu JC, Vilar C, Vinagre F, Baldani JI, Hemerly AS. 2005. Characterization of glutamine synthetase genes in sugarcane genotypes with different rates of biological nitrogen fixation. Plant Science 169: 819-832.

Oaks A. 1992. A reevaluation of nitrogen assimilation in roots. Bioscience 42: 103-111.

Obara M, Kajiura M, Fukuta Y, Yano M, Hayashi M, Yamaya T, Sato T. 2001. Mapping of QTLs associated with cytosolic glutamine synthetase and NADH-glutamate synthase in rice (Oryza sativa L.). Journal of Experimental Botany 52: 1209-1217.

Obara M, Sato T, Sasaki S, Kashiba K, Nagano A, Nakamura I, Ebitani T, Yano M, Yamaya T. 2004. Identification and characterization of a QTL on chromosome 2 for cytosolic glutamine synthetase content and panicle number in rice. Theoretical and Applied Genetics 110: 1-11.

Oldroyd GED, Downie JM. 2008. Coordinating nodule morphogenesis with rhizobial infection in legumes. Annual Review of Plant Biology 59: 519-546.

Oléa F, Pérez-García A, Cantón FR, Rivera ME, Canas R, Ávila C, Cazorla FM, Cánovas FM, de Vicente A. 2004. Up-regulation and localization of asparagine synthetase in tomato leaves infected by the bacterial pathogen Pseudomonas syringae. Plant and Cell Physiology 45: 770-780.

Oliveira IC, Brears T, Knight TJ, Clark A, Coruzzi GM. 2002. Overexpression of cytosolic glutamine synthetase. Relation to nitrogen, light, and photorespiration. Plant Physiology 129: 1170-1180.

Orea A, Pajuelo P, Pajuelo E, Quidiello C, Romero JM, Márquez AJ. 2002. Isolation of photorespiratory mutants from Lotus japonicus deficient in glutamine synthetase. Physiologia Plantarum 115: 352-361.

Ortega JL, Moguel-Esponda S, Potenza C, Conklin CF, Quintana A, Sengupta-Gopalan C. 2006. The 3' untranslated region of a soybean cytosolic glutamine synthetase (GS1) affects transcript stability and protein accumulation in transgenic alfalfa. Plant Journal 45: 832-846.

Ortega JL, Temple SJ, Bagga S, Ghoshroy S, Sengupta-Gopalan C. 2004. Biochemical and molecular characterization of transgenic Lotus japonicus plants constitutively over-expressing a cytosolic glutamine synthetase gene. Planta 219: 807-818.

Pageau K, Reisdorf-Cren M, Morot-Gaudry JF, Masclaux-Daubresse C. 2006. The two senescence-related markers, GS1 (cytosolic glutamine synthetase) and GDH (glutamate dehydrogenase), involved in nitrogen mobilization, are differentially regulated during pathogen attack and by stress hormones and reactive oxygen species in Nicotiana tabacum $\mathrm{L}$. Leaves. Journal of Experimental Botany 57: 547-557.

Paul EA, Clark FE. 1996. Soil microbiology and biochemistry, 2nd edn. San Diego, CA, USA: Academic Press Ltd.

Peat LJ, Tobin AK. 1996. The effect of nitrogen nutrition on the cellular localization of glutamine synthetase isoforms in barley roots. Plant Physiology 111: 1109-1117.

Pérez-García A, Cánovas FM, Gallardo F, Hirel B, de Vicente A. 1995. Differential expression of glutamine synthetase isoforms in tomato detached leaflets infected with Pseudomonas syringae pv tomato. Molecular Plant-Microbe Interactions 8: 96-103.

Pérez-García A, de Vicente A, Cantón FR, Cazorla FM, Codina JC, Garcia-Gutierrez A, Cánovas FM. 1998a. Light-dependent changes of tomato glutamine synthetase in response to Pseudomonas syringae infection or phosphinothricin treatment. Physiologia Plantarum 102: 377-384.
Pérez-García A, Pereira S, Pissarra J, Gutiérrez AG, Cazorla FM, Salema R, de Vicente A, Cánovas FM. 1998b. Cytosolic localization in tomato mesophyll cells of a novel glutamine synthetase induced in response to bacterial infection or phosphinothricin treatment. Planta 206: 426-434.

Pérez-Rodríguez J, Valpuesta V. 1996. Expression of glutamine synthetase genes during natural senescence of tomato leaves. Physiologia Plantarum 97: 576-582.

Pesole G, Bozzetti MP, Lanave C, Preparata G, Saccone C. 1991. Glutamine synthetase gene evolution - a good molecular clock. Proceedings of the National Academy of Sciences, USA 88: 522-526.

Rai AN, Soderback E, Bergman B. 2000. Cyanobacterium-plant symbioses. New Phytologist 147: 449-481.

Rastogi R, Chourey PS, Muhitch MJ. 1998. The maize glutamine synthetase $G S_{1-2}$ gene is preferentially expressed in kernel pedicels and is developmentally-regulated. Plant and Cell Physiology 39: 443-446.

Reisdorf-Cren M, Carrayol E, Terce-Laforgue TR, Hirel B. 2002. A novel HMG A-like protein binds differentially to the AT-rich regions located in the far distal and proximal parts of a soybean glutamine synthetase gene (GS15) promoter. Plant and Cell Physiology 43: 1006-1016.

Rodriguez MJP, Suárez MF, Heredia R, Ávila C, Breton D, Trontin JF, Filonova L, Bozhkov $P$, von Arnold S, Harvengt $\mathrm{L}$ et al. 2006. Expression patterns of two glutamine synthetase genes in zygotic and somatic pine embryos support specific roles in nitrogen metabolism during embryogenesis. New Phytologist 169: 35-44.

Sáez CA, Muñoz-Chapuli R, Plomion C, Frigerio JM, Cánovas FM. 2000. Two genes encoding distinct cytosolic glutamine synthetases are closely linked in the pine genome. FEBS Letters 477: 237-243.

Sakakibara H, Kawabata S, Takahashi H, Hase T, Sugiyama T. 1992. Molecular cloning of the family of glutamine synthetase genes from maize - expression of genes for glutamine synthetase and ferredoxin-dependent glutamate synthase in photosynthetic and nonphotosynthetic tissues. Plant and Cell Physiology 33: 49-58.

Sakakibara H, Shimizu H, Hase T, Yamazaki Y, Takao T, Shimonishi Y, Sugiyama T. 1996. Molecular identification and characterization of cytosolic isoforms of glutamine synthetase in maize roots. Journal of Biological Chemistry 271: 29561-29568.

Sakurai N, Hayakawa T, Nakamura T, Yamaya T. 1996. Changes in the cellular localization of cytosolic glutamine synthetase protein in vascular bundles of rice leaves at various stages of development. Planta 200: 306-311.

Sakurai N, Katayama Y, Yamaya T. 2001. Overlapping expression of cytosolic glutamine synthetase and phenylalanine ammonia-lyase in immature leaf blades of rice. Physiologia Plantarum 113: 400-408.

Santos C, Pereira A, Pereira S, Teixeira J. 2004. Regulation of glutamine synthetase expression in sunflower cells exposed to salt and osmotic stress. Scientia Horticulturae 103: 101-111.

Sauter JJ, van Cleve B. 1992. Seasonal variation of amino acids in the xylem sap of Populus $\times$ canadensis and its relation to protein body mobilization. Trees Structure and Function 7: 26-32.

Schimel JP, Bennett J. 2004. Nitrogen mineralization: challenges of a changing paradigm. Ecology 85: 591-602.

Schjoerring JK, Kyllingsbaek A, Mortensen JV, Byskovnielsen S. 1993. Field investigations of ammonia exchange between barley plants and the atmosphere. 2. Nitrogen reallocation, free ammonium content and activities of ammonium-assimilating enzymes in different leaves. Plant, Cell \& Environment 16: 169-178.

Shewry PR, Halford NG. 2002. Cereal seed storage proteins: structures, properties and role in grain utilization. Journal of Experimental Botany 53: 947-958.

Sonoda Y, Ikeda A, Saiki S, Yamaya T, Yamaguchi J. 2003. Feedback regulation of the ammonium transporter gene family $A M T 1$ by glutamine in rice. Plant and Cell Physiology 44: 1396-1402.

Stanford AC, Larsen K, Barker DG, Cullimore JV. 1993. Differential expression within the glutamine synthetase gene family of the model legume Medicago truncatula. Plant Physiology 103: 73-81. 
Stitt M, Schulze D. 1994. Does Rubisco control the rate of photosynthesis and plant growth - an exercise in molecular ecophysiology. Plant, Cell \& Environment 17: 465-487.

Suárez MF, Ávila C, Gallardo F, Cantón FR, García-Gutiérrez A, Claros MG, Cánovas FM. 2002. Molecular and enzymatic analysis of ammonium assimilation in woody plants. Journal of Experimental Botany 53: 891-904

Sukanya R, Li MG, Snustad DP. 1994. Root-specific and shoot-specific responses of individual glutamine synthetase genes of maize to nitrate and ammonium. Plant Molecular Biology 26: 1935-1946.

Tabuchi M, Abiko T, Yamaya T. 2007. Assimilation of ammonium ions and reutilization of nitrogen in rice (Oryza sativa L.). Journal of Experimental Botany 58: 2319-2327.

Tabuchi M, Sugiyama K, Ishiyama K, Inoue E, Sato T, Takahashi H, Yamaya T. 2005. Severe reduction in growth rate and grain filling of rice mutants lacking $O s G S 1 ; 1$, a cytosolic glutamine synthetase1;1. Plant Journal 42: 641-651.

Tavernier V, Cadiou S, Pageau K, Lauge R, Reisdorf-Cren M, Langin T, Masclaux-Daubresse C. 2007. The plant nitrogen mobilization promoted by Colletotrichum lindemuthianum in Phaseolus leaves depends on fungus pathogenicity. Journal of Experimental Botany 58: 3351-3360.

Teixeira J, Pereira S. 2007. High salinity and drought act on an organdependent manner on potato glutamine synthetase expression and accumulation. Environmental and Experimental Botany 60: 121-126.

Teixeira J, Pereira S, Cánovas F, Salema R. 2005. Glutamine synthetase of potato (Solanum tuberosum L. cv. Desiree) plants: cell- and organ-specific expression and differential developmental regulation reveal specific roles in nitrogen assimilation and mobilization. Journal of Experimental Botany 56: 663-671

Temple SJ, Knight TJ, Unkefer PJ, Senguptagopalan C. 1993. Modulation of glutamine synthetase gene expression in tobacco by the introduction of an alfalfa glutamine synthetase gene in sense and antisense orientation: molecular and biochemical analysis. Molecular \& General Genetics 236: 315-325.

Tercé-Laforgue T, Carrayol E, Cren M, Desbrosses G, Hecht V, Hirel B. 1999. A strong constitutive positive element is essential for the ammonium-regulated expression of a soybean gene encoding cytosolic glutamine synthetase. Plant Molecular Biology 39: 551-564.

Tingey SV, Walker EL, Coruzzi GM. 1987. Glutamine-synthetase genes of pea encode distinct polypeptides which are differentially expressed in leaves, roots and nodules. EMBO Journal 6: 1-9.

Tobin AK, Ridley SM, Stewart GR. 1985. Changes in the activities of chloroplast and cytosolic isoenzymes of glutamine synthetase during normal leaf growth and plastid development in wheat. Planta 163: 544-548.

Tobin AK, Yamaya T. 2001. Cellular compartmentation of ammonium assimilation in rice and barley. Journal of Experimental Botany 52: 591-604

Unno H, Uchida T, Sugawara H, Kurisu G, Sugiyama T, Yamaya T, Sakakibara H, Hase T, Kusunoki M. 2006. Atomic structure of plant glutamine synthetase - a key enzyme for plant productivity. Journal of Biological Chemistry 281: 29287-29296.

Vance CP, Gregerson RG, Robinson DL, Miller SS, Gantt JS. 1994. Primary assimilation of nitrogen in alfalfa nodules - molecular-features of the enzymes involved. Plant Science 101: 51-64.

Vincent R, Fraisier V, Chaillou S, Limami MA, Deleens E, Phillipson B, Douat C, Boutin JP, Hirel B. 1997. Overexpression of a soybean gene encoding cytosolic glutamine synthetase in shoots of transgenic Lotus corniculatus L. plants triggers changes in ammonium assimilation and plant development. Planta 201: 424-433.

Wallace W. 1986. Distribution of nitrate assimilation between the root and shoot of legumes and a comparison with wheat. Physiologia Plantarum 66: 630-636.

Wallsgrove RM, Turner JC, Hall NP, Kendall AC, Bright SWJ. 1987. Barley mutants lacking chloroplast glutamine synthetase - biochemical and genetic analysis. Plant Physiology 83: 155-158.

Woodall J, Boxal JG, Forde BG, Pearson J. 1996. Changing perspectives in plant nitrogen metabolism: the central role of glutamine synthetase. Science Progress 79: 1-26.

Woodall J, Forde BG. 1996. Glutamine synthetase polypeptides in the roots of 55 legume species in relation to their climatic origin and the partitioning of nitrate assimilation. Plant, Cell \& Environment 19: 848-858.

Yamaya T, Oaks A. 1988. Distribution of 2 isoforms of glutaminesynthetase in bundle sheath and mesophyll-cells of corn leaves. Physiologia Plantarum 72: 23-28.

Yamaya T, Oaks A. 2004. Metabolic regulation of ammonium uptake and assimilation. In: Stulen I, Amancio S, eds. Nitrogen acquisition and assimilation in higher plants. Dordrecht, The Netherlands: Kluwer Academic Publisher, 35-64.

Yamaya T, Obara M, Nakajima H, Sasaki S, Hayakawa T, Sato T. 2002. Genetic manipulation and quantitative-trait loci mapping for nitrogen recycling in rice. Journal of Experimental Botany 53: 917-925.

Yan SP, Tang ZC, Su W, Sun WN. 2005. Proteomic analysis of salt stressresponsive proteins in rice root. Proteomics 5: 235-244.

Zozaya-Hinchliffe M, Potenza C, Ortega JL, Sengupta-Gopalan C. 2005. Nitrogen and metabolic regulation of the expression of plastidic glutamine synthetase in alfalfa (Medicago sativa). Plant Science 168: 1041-1052. 